\title{
Multiplicity of Buc copies in Atlantic salmon contrasts with loss of the germ cell determinant in primates, rodents and axolotl
}

Adrijana Škugor ${ }^{1}$, Helge Tveiten ${ }^{2}$, Hanne Johnsen ${ }^{2}$ and Øivind Andersen ${ }^{1,3^{*}}$ (D)

\begin{abstract}
Background: The primordial germ cells (PGCs) giving rise to gametes are determined by two different mechanisms in vertebrates. While the germ cell fate in mammals and salamanders is induced by zygotic signals, maternally delivered germ cell determinants specify the PGCs in birds, frogs and teleost fish. Assembly of the germ plasm in the oocyte is organized by the single Buc in zebrafish, named Velo1 in Xenopus, and by Oskar in Drosophila. Secondary loss of oskar in several insect lineages coincides with changes in germline determination strategies, while the presence of buc in mammals suggests functions not associated with germline formation.

Results: To clarify the evolutionary history of buc we searched for the gene in genomes available from various chordates. No buc sequence was found in lamprey and chordate invertebrates, while the gene was identified in a conserved syntenic region in elephant shark, spotted gar, teleosts, Comoran coelacanth and most tetrapods. Rodents have probably lost the buc gene, while a premature translation stop was found in primates and in Mexican axolotl lacking germ plasm. In contrast, several buc and buc-like (bucL) paralogs were identified in the teleosts examined, including zebrafish, and the tetraploid genome of Atlantic salmon harbors seven buc and bucL genes. Maternal salmon buc1a, buc2a and buc2b mRNAs were abundant in unfertilized eggs together with dnd and vasa mRNAs. Immunostained salmon Bucla was restricted to cleavage furrows in 4-cell stage embryos similar to a fluorescent zebrafish Buc construct injected in salmon embryos. Salmon Buc1a and Buc2a localized together with DnD, Vasa and Dazl within the Balbiani body of early oocytes.

Conclusions: Buc probably originated more than 400 million years ago and might have played an ancestral role in assembling germ plasm. Functional redundancy or subfunctionalization of salmon Buc paralogs in germline formation is suggested by the maternally inherited mRNAs of three salmon buc genes, the localized Buc1a in the cleavage furrows and the distribution of Bucla and Buc2a in the Balbiani body during oogenesis. The extra-ovarian expression of salmon buc genes and the presence of a second zebrafish bucL gene suggest additional functions not related to germ cell specification.
\end{abstract}

Keywords: Bucky ball, Germ plasm, Oskar, Mexican axolotl, Germline, Balbiani body

\footnotetext{
* Correspondence: oivind.andersen@nofima.no

${ }^{1}$ Norwegian University of Life Sciences (NMBU), PO Box 5003, N-1430 Ås,

Norway

${ }^{3}$ Nofima, PO Box 5010, N-1430 Ås, Norway

Full list of author information is available at the end of the article
} 


\section{Background}

Segregation of the germline and the specification of germ cells to become gametes are fundamental features in the animal kingdom, but the primordial germ cells (PGCs) are determined by two different mechanisms; zygotic induction (epigenesis) or cytoplasmic inheritance (preformation). PGCs are induced from pluripotent cells by extracellular signals in species with the inductive mechanism that involves BMP signals and the transcriptional repressor Blimp1 in mice and Mexican axolotl (Ambystoma mexicanum) [1-4]. The inductive mode of germline determination is found in basal chordates, salamanders, turtles and mammals, and is thought to be the ancestral mechanism [5-7]. Germ cells within teleost fish, frogs, snakes and birds acquire their fate early in embryogenesis through maternally deposited germ cell determinants known as germ plasm [6, 8]. The germ cell-specific mRNAs and proteins include Dazl, Dead end (Dnd) and Vasa, which are crucial for germline formation [9-15]. The conserved genes are expressed in the PGCs of all vertebrates, but the mRNAs and proteins are found dispersed in mouse, turtle and salamander, while they are localized in the germ plasm within the Balbiani body of zebrafish, Atlantic salmon, Xenopus and chicken $[5,16-21]$. This mitochondria-rich organelle is one of the first morphological markers of oocyte polarity, but shows considerable variability in composition, morphology, developmental timing and persistence among metazoans [22].

Germ plasm assembly and cell-autonomous PGC specification have been demonstrated to be controlled by a single gene in the model species Drosophila, zebrafish and Xenopus [23-27]. In Drosophila, oskar is necessary and sufficient for the assembly of germ plasm in the oocyte posterior pole and the early specification of PGCs named pole cells $[28,29]$. Knock-down of oskar in the wasp Nasonia vitripennis resulted in disrupted germ plasm and no pole cells, but defects in somatic patterning suggest complex roles of Oskar outside of the germline as well [30]. Intriguingly, oskar was found to have predated the evolution of germ plasm in insects by the identification of an ortholog in the cricket Gryllus bimaculatus that is not required for germ cell formation or axial patterning, but is necessary for neural development [31]. Although no detectable homology, the function of Oskar is remarkable similar to zebrafish Buc and Xenopus Velo1, which are characterized by a conserved N-terminal BUVE (Buc-Velo) motif. The novel region interacts with the RNA-binding protein Hermes to initiate Balbiani body assembly probably by recruiting buc and other RNAs, including dazl, to the germ plasm [27, 32]. Zebrafish buc mutant oocytes failed to localize dazl mRNAs in the Balbiani body that resulted in embryos without animal-vegetal polarity $[23,26]$. Furthermore, the buc mutants possessed excess micropyles causing polyspermy, whereas overexpression of zebrafish buc seemed to generate ectopic PGCs in the embryo [23]. In Xenopus, two splice variants of Velo1 probably play largely redundant roles and are essential for germ plasm formation and maintenance [24, 27].

Orthologs of buc have been identified in several teleosts, chicken and mammals, but our knowledge about its key role in germ plasm assembly and oocyte asymmetry is solely based on studies in zebrafish and Xenopus [23, 25-27]. Paralog loss has apparently occurred in the two model species after the whole genome duplication events in teleosts and in X. laevis about 350 and 40 Mya, respectively. Tandem duplicates of buc have been reported in mammals and pufferfish [23] suggesting additional functions of Buc besides germline specification. In this study we examined the evolutionary history of Buc and the fate of the gene in vertebrates lacking germ plasm. Whereas a functional Buc has been lost in primates, rodents and axolotl, we found duplicated genes in all teleosts examined and possible redundancy of the Buc paralogs was investigated in the tetraploid Atlantic salmon.

\section{Results}

\section{Origin and distribution of buc in vertebrates}

We searched for the buc gene in multiple chordate species representing key phylogenetic lineages by performing genomic BLAST search. No buc-related sequence was found in tunicates (Ciona intestinalis and C. savignyi), amphioxus (Branchiostoma lanceolatum and B. floridae), acorn worm (Saccoglossus kowalevskii) and in sea lamprey (Petromyzon marinus), while the elephant shark (Callorhinchus milii) genome was shown to harbor a single buc gene positioned next to the kbtbd2, avl9 and lsmes genes (Fig. 1). The syntenic region was found to be conserved in Comoran coelacanth (Latimeria chalumnae), spotted gar (Lepisosteus oculatus), teleosts and in most tetrapods, but the number of buc genes varied. Cow and dog possess three and two genes copies, respectively, including pseudogenes (Additional file 1: Figure S1), while rodents seem to have lost the $b u c$ gene. The neighbor genes are conserved in mouse and rat, but are positioned next to a large rodent-specific gene cluster of vomeronasal receptors [33]. The single primate $b u c$ is a pseudogene with a premature translation stop after 20 amino acids (aa), while gorilla has an additional mutation in the translation start signal (Additional file 2: Figure S2). The complete buc gene was identified in the genome of Tasmanian devil (Sarcophilus harrisii), kangaroo rat (Dipodomys ordii), opossum (Monodelhis domstica), while a shorter Buc protein of 426 aa was predicted from platipus (Ornithorhyncus anatinus) (Additional file 3: Table S1). Blasting the axolotl genome against Xenopus velo1 revealed a single base deletion that introduces a premature translation stop 


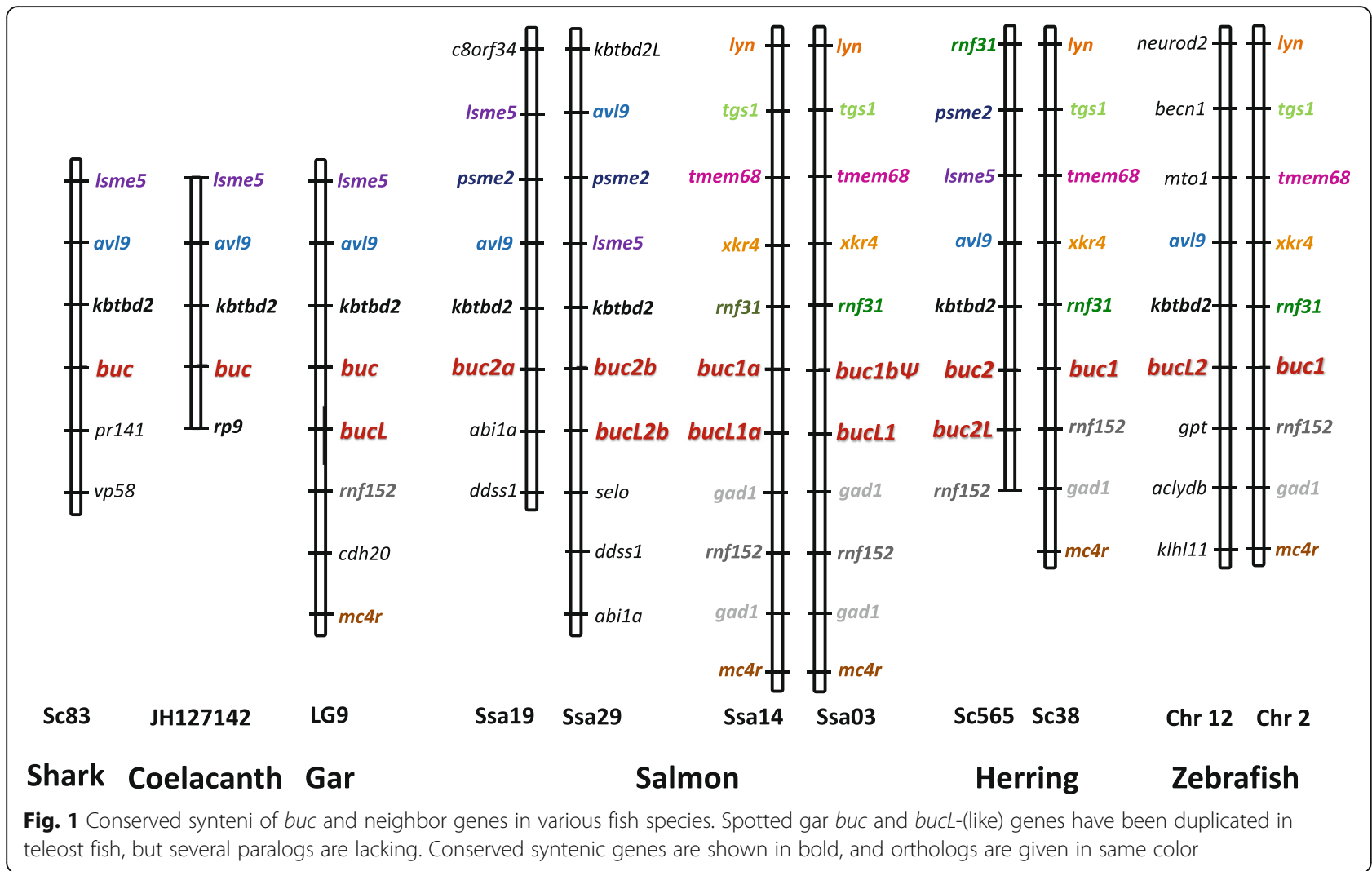

(Additional file 4: Figure S3). The truncated axolotl Buc of 190 aa shares only $52 \%$ identity with Xenopus Velo1 and contains no N-terminal BUVE motif. The phylogenetic analysis of vertebrate Buc proteins showed that tetrapods form a separate clade together with the coelacanth, while the elephant shark branches off basal to the tetrapods (Fig. 2).

Spotted gar was shown to possess tandem repeated genes designated $b u c$ and buc-like (bucL) (Fig. 1), and additional duplications have likely occurred in teleosts during the third round of whole-genome duplication. Despite widespread paralog loss, a paralogon containing duplicated copies of buc and bucL was found in several species, including salmon, herring and zebrafish (Fig. 1). We named the buc paralog flanked by rnf31 and rnf152 as $b u c 1$, while $b u c 2$ designates the paralog next to the kbtbd2-avl9-lsme5 block. Consistently, the phylogenetic analysis separated Buc1 and Buc2 in two clusters, but the latter showed low bootstrap values (Fig. 2). Both paralogs were identified in salmon, herring, pike and cavefish, while buc1 has been lost in most species examined (Fig. 2). Conversely, buc2 is lacking in zebrafish, which has retained bucL2 sharing only $30 \%$ aa sequence identity with bucl (named buc in previous studies). The tetraploid Atlantic salmon genome was shown to harbor a total of seven buc genes positioned on the homeologous chromosomes Ssa14 - Ssa03 and Ssa19 - Ssa29 that comprised four buc genes, including the buclb pseudogene, and three bucL genes (Fig. 1). All predicted salmon Buc proteins possess a conserved N-terminal BUVE-motif, but repeats were found in the BucL2b motif (Additional file 5: Figure S4).

\section{Maternal mRNAs of three buc, dnd and vasa in salmon embryo}

We quantified the mRNA levels of salmon bucla, buc $2 a$ and $b u c 2 b$ during embryogenesis using RT-qPCR. Maternal deposition of the three transcripts was evidenced by the high mRNA levels in unfertilized eggs that gradually decreased during embryogenesis (Fig. 3). Similar mRNA patterns were found in the germ plasm factors $d n d$ and vasa, and only bucla and vasa mRNAs were maintained at the onset of gastrulation.

\section{Salmon Buc1a and injected zebrafish Buc-GFP in cleavage furrows}

Specific antibodies were produced against salmon Bucla, Buc2a and Buc2b to localize the proteins in the developing embryo and in the ovary. Immunostaining of 4-cell embryos revealed Bucla aggregates within the cleavage furrows similar to the localization of zebrafish Buc-GFP after injection of the mRNA construct in 1-cell salmon embryo (Fig. 4a, b). The intensity of fluorescence in the putative PGCs at segmentation stage (Fig. 4c) varied 


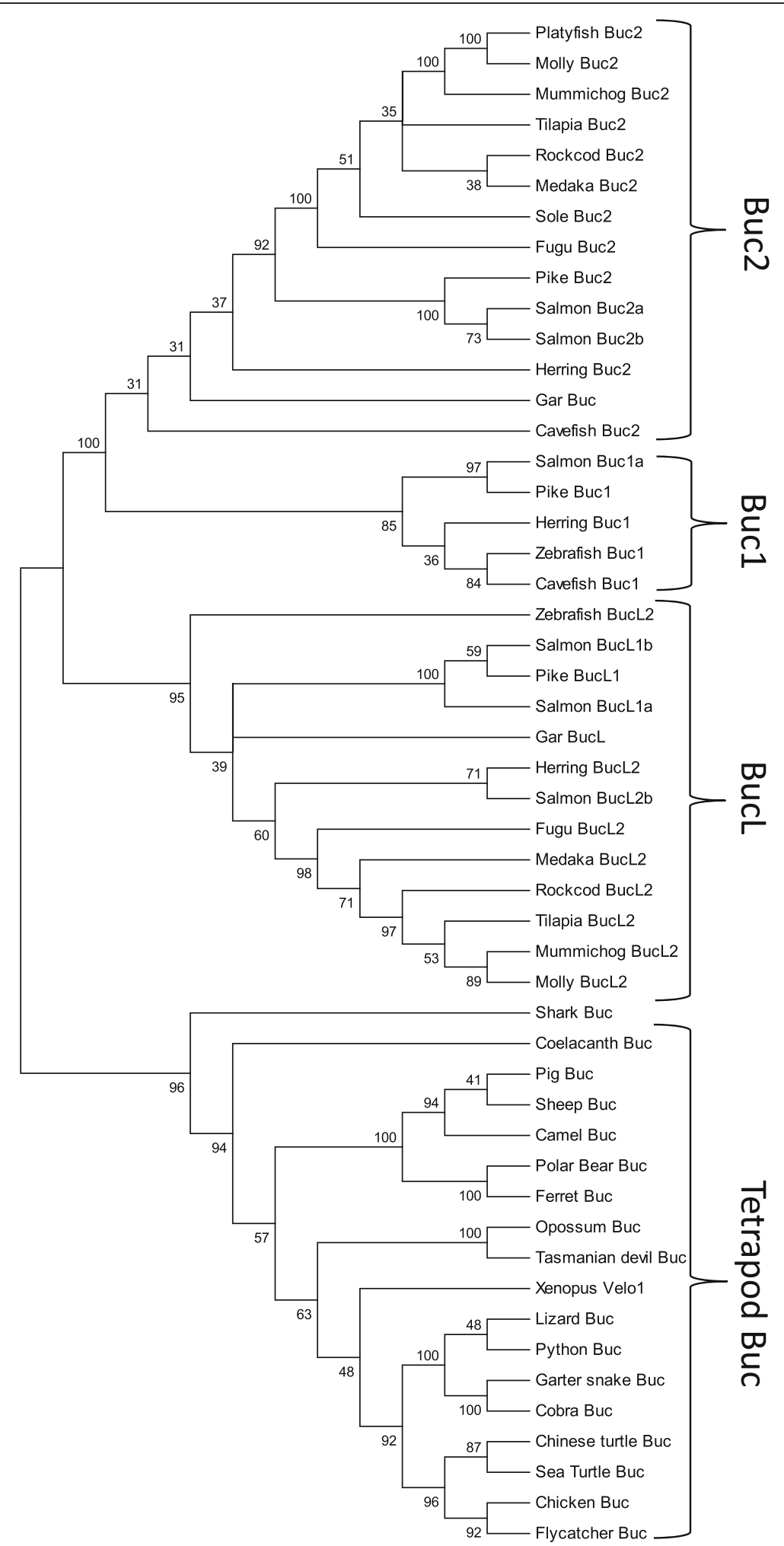

Fig. 2 Unrooted phylogenetic tree of tetrapod Buc proteins and teleost Buc and BucL (-like) paralogs. The tree was generated using the ML method based on the JTT model. To evaluate the topological stability 100 bootstrap resamplings were made. All branches with less than 30 bootstrap confidence values were collapsed. Accession numbers are given in Additional file 3: Table S1 


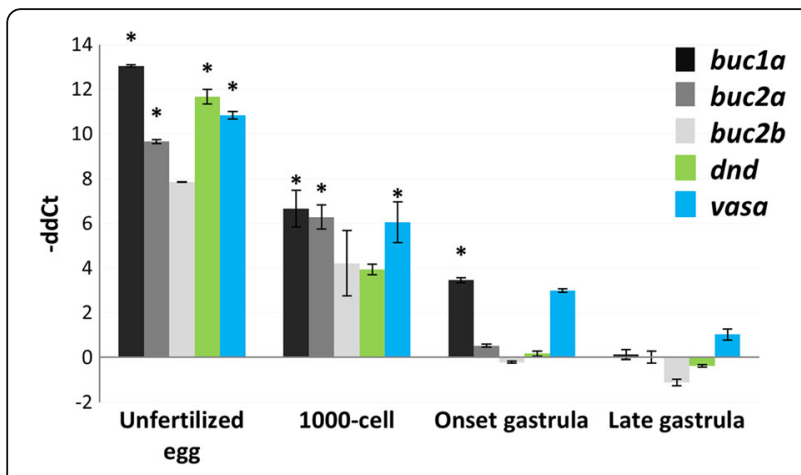

Fig. 3 mRNA levels of salmon buc1a, buc2a and buc2b together with $d n d$ and vasa during embryogenesis. The transcriptional levels of target genes were normalized to eEf1-a and presented as $-\Delta \Delta C \mathrm{Ct} \pm \mathrm{SE}$ $(n=3)$. All stages were compared to the segmentation stage that follows late gastrulation. Significant difference is marked with * $(p<0.05)$

between embryos when different doses of the construct were injected. The position and morphology of the bucexpressing cells resembled the salmon PGCs labelled at the same stage using cod Nanos3-GFP mRNA reporter [34]. The Buc2a protein was not detected in the salmon embryo, while the Buc2b antibodies did not work satisfactorily.

\section{Gene expression of salmon buc, dnd and vasa during oogenesis}

Salmon buc1a, buc $2 a$ and buc $2 b$ were all expressed in the ovary during oogenesis with the highest mRNA levels measured in the maturing ovary of 2-year old females (Fig. 5a). The expression profiles of $d n d$ and vasa were similar to the $b u c$ genes, including the higher levels in the maturing 2-year old ovary than in the juveniles and in the mature ovary of 3-year old females.

Extra-ovarian expression of the three salmon buc genes was measured together with $d n d$ and vasa in 2-year old females (Fig. 5b). The three genes showed abundant expression in ovary, but the transcripts were widely distributed in other tissues. Low levels of $b u c 1 a$ mRNA were found in gills, while $b u c 2 a$ and $b u c 2 b$ displayed substantial expression in the pituitary and skeletal muscle, respectively. The $d n d$ and vasa genes were highly expressed in the ovary, while tissues like brain and gills showed low mRNA levels.

\section{Localization of salmon Buc, Dnd and Vasa proteins during oogenesis}

Immunostaining of ovarian sections from 2-year old females showed both Bucla and Buc2b signals at the periphery of the granular ooplasm of immature oocytes similar to the localization of Vasa (Fig. 6a, b, c). Dnd and Dazl were distributed in the granular ooplasm and nucleoli of immature oocytes, but were also visualized in the cytoplasma of granulosa cells surrounding the mature oocytes at the cortical alveolus stage (Fig. 6d, e). We further examined the location of Bucla and Vasa in the juvenile ovary containing primary growth oocytes (stage 2a, 2b), and showed that the two proteins colocalized in the granular ooplasm within the putative Balbiani body (Fig. 7).

\section{TEM analyses of salmon ovary}

To get a more detailed overview of oocyte structures in salmon ovaries at different developmental stages, we performed TEM analyses of ovaries from juvenile and 2-year old females (Fig. 8). Juvenile ovaries consisted exclusively of the primary growth stage 2 oocytes with irregular, electron dense nucleus and a cytoplasm without yolk granules (Fig. 8a). At this stage, accumulations of nuage were observed nearby nuclear envelope and numerous nucleoli, but also in the cytoplasm in close proximity to small vesicle and mitochondrial aggregates. TEM analysis revealed two distinct cytoplasmic zones in stage 2 oocytes; granular and homogenous (Fig. 8a). Interestingly, granular cytoplasm was rich in organelles comprising mitochondria, Golgi, ER and nuage (Fig. 8b, c). In contrast, ovaries from 2-year old females consisted of different oocyte
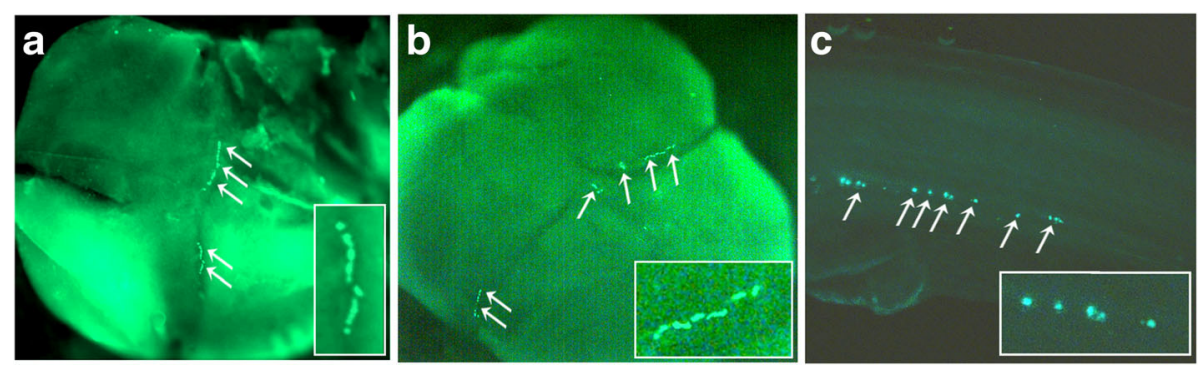

Fig. 4 Salmon embryo at 4-cell stage with fluorescent signals in cleavage furrows from: a Immunostained endogenous Bucla protein, b Zebrafish Buc-GFP injected in 1-cell salmon embryos. Magnified signals are shown in the white box. c Zebrafish Buc-GFP localized to putative PGCs in salmon embryos during segmentation. White arrows indicate fluorescent signals. Immunostained salmon embryo with secondary antibody only is shown in Additional file 8: Figure S5 


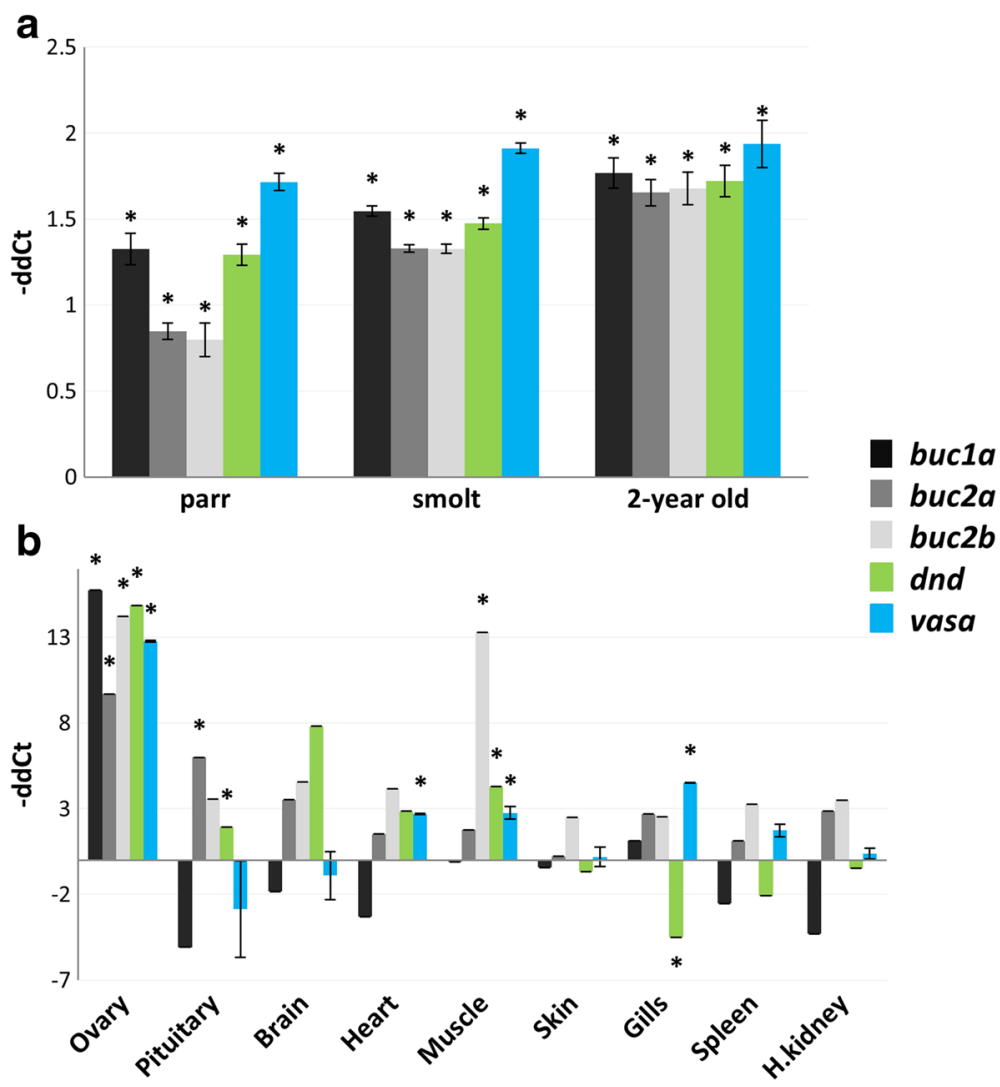

Fig. 5 Gene expression of salmon buc1, buc2a, buc2b, dnd and vasa. a Ovarian mRNA levels during oogenesis at the freshwater (parr) and early seawater (smolt) stages compared to those in 3-year old ovary $(n=6)$. b Tissue expression in 2-year old females $(n=2)$. All tissues were compared to liver. The transcriptional levels of target genes were normalized to eEf1-a. Data are presented as $-\Delta \Delta \mathrm{Ct} \pm \mathrm{SE}$. Significant difference is marked with * $(p<0.05)$

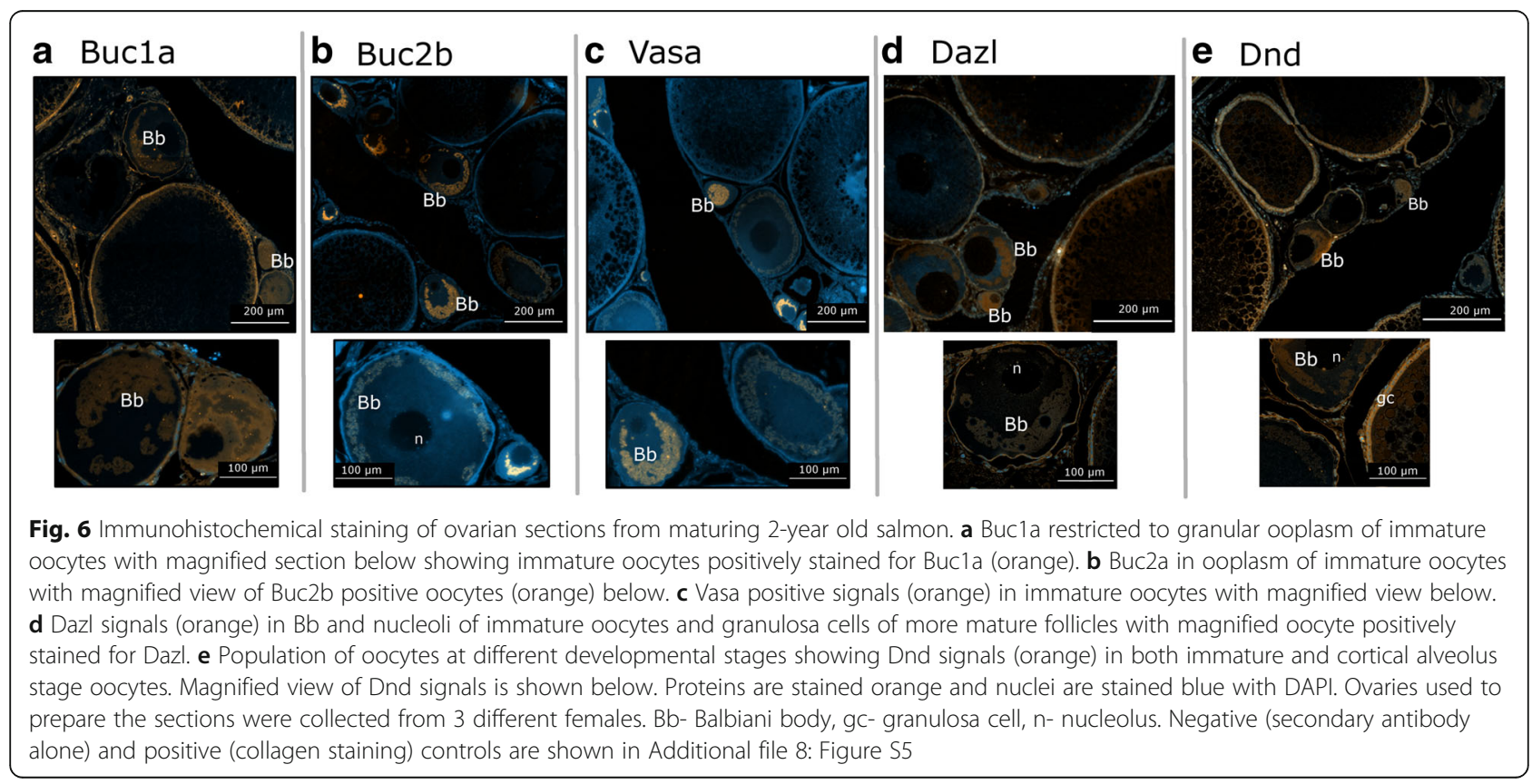





Fig. 7 Immunohistochemical staining of juvenile ovarian sections. Adjacent sections were used for staining of (a) Bucla (orange) and (b) Vasa (orange). c Co-localization of Bucla and Vasa in the granular ooplasm of primary growth oocytes. Ovaries used to prepare the sections were collected from 3 different females. Nuclei were stained with DAPI (blue); Bb- Balbiani body, on- oocyte nucleus

populations. In addition to immature pre-vitellogenic oocytes, we observed a large population of cortical alveolus stage oocytes, which were substantially larger and contained yolk vesicles (cortical alveoli) of various sizes and showed more pronounced follicle epithelium (Fig. 8d). All oocytes were surrounded by follicle cells with characteristic, elongated nucleus (Fig. 8a, c, d). In rainbow trout, the Balbiani body disappear in the oocytes at stages 3 and 4 [35] corresponding to the lowered mRNA levels and the absence of salmon Buc proteins in the mature oocytes prior to spawning. Consistently, the zebrafish Buc protein was undetectable in stage III oocytes, while the mRNA levels were reduced at stage IV $[23,36]$.

\section{Discussion}

This study traced the evolutionary origin of Buc back to more than 400 million years (mya) at the time cartilaginous fish appeared and lobe-finned fish (Sarcopterygii) separated from ray-finned fish (Actinopterygii). This agrees with the recent identification of ovarian buc in the Chinese sturgeon (Acipenser sinensis) representing the primitive Acipenseriformes with estimated origin time about 390 mya [37, 38]. The Balbiani body and specification pattern of the sturgeon PGCs were shown to closely resemble that of anurans, and injected zebrafish Buc-GFP accumulated at the cleavage furrows similar to our salmon study [39, 40]. Together with the localization of sturgeon dazl in the Balbiani body [41], the results suggest the involvement of Buc in the germ plasm assembly of this basal ray-finned fish. In cartilaginous fish, most researchers have identified germ cells first at late embryonic stages indicating zygotic induction $[6,42]$. Furthermore, while the mode of germ cell specification in coelacanths is unknown, no mitochondrial cloud was found in oocytes of lungfish suggesting that germ plasm was absent in the common ancestor of tetrapods [7]. However, this should be confirmed by molecular analysis of the germ cell determinants available from recent studies of the coelacanth genome and lungfish transcriptome $[43,44]$. It should be noted that


Fig. 8 Ultrastructure of Atlantic salmon oocytes. a Stage 2 oocytes with granular ooplasm/Balbiani body. Black arrows indicate accumulations of nuage close to nuclear envelope and numerous nucleoli. b An area with aggregates of nuage and numerous mitochondria. c Ooplasm of stage 2 oocytes with endoplasmic reticulum and Golgi complex near the nuclear membrane. d Stage 4 oocyte surrounded with follicular cells. BL-basal membrane; CA-cortical alveoli; CT-connective tissue; ER-endoplasmic reticulum; GC-Golgi complex; GO-granular ooplasm; GRC-granulosa cell; HO- homogeneous ooplasm; LB-lipid body; M-mitochondria; NU-nuage; N-nucleus; n-nucleolus; TC-theca cell 
cephalochordate PGCs were suggested to be epigenetically determined based on the first morphological identification of germ cells, whereas more recent studies have revealed maternal transcripts of tudor7, vasa and nanos co-localized in germ plasm that implies a function in germ cell formation $[6,45,46]$. In ascidian, the germline is silenced and primary cell lineages are determined by maternal postplasmic/PEM mRNAs [47-50], which might include a novel germ cell determinant yet to be found.

The repeated emergence of predetermined germ cells in different lineages suggests that the molecular regulator underlying maternal germ plasm assembly in principle is relatively easily acquired $[7,51]$. The maternally inherited and zygotic inductive modes of germline formation have been studied in a few model species, and both mechanisms seem to require a single, or only a few, specific gene(s) expressed at the appropriate developmental stage, subcellular localization and dosage to direct germ cell specification [52-55]. The two strategies are used in amphibians wherein frogs (anurans) employ germ plasm, while salamanders (urodeles) do not $[5,17,56]$. Xenopus has lost the pluripotency genes nanog and oct4, but exhibits multiple gene copies of Nodal-related and mix regulating mesoderm development [57]. In contrast, axolotl has single copies of these genes and the PGCs are eliminated by excess Nodal levels and overexpression of mix, suggesting strict regulation of these genes in species with zygotic induction $[1,57,58]$. Conversely, germ plasm assembly in Xenopus is controlled by the Buc homolog Velo1, while only a partial buc sequence seem to have been retained in axolotl after the anurans and urodeles diverged from a common ancestor about 250 million years ago $[59,60]$. Secondary loss of a functional Buc was also shown in rodents lacking the gene and in primates possessing only a pseudogene, whereas the gene has been conserved in nonprimates and in turtles, which are using the inductive strategy [61]. The conserved syntenic region of buc has escaped chromosome rearrangements over a long evolutionary period and suggests a strong selective pressure on the region. We therefore propose that Buc played an ancestral role in germline formation and functions as the common regulator assembling the conserved germ plasm components in vertebrates with preformation. Altogether this suggests that the preformation mode was the ancestral mechanism and that the inductive mode has evolved repeatedly in vertebrates.

Tandem duplicated buc genes were found in spotted gar resembling the local gene duplications previously reported in several non-primate mammals [23]. The buc and bucL copies have been further duplicated in teleosts, but paralogs have apparently been lost after the third whole genome duplication event. In zebrafish, the Buc1 paralog is necessary and sufficient for germ plasm assembly and oocyte polarity [23], while the BUVE motif is not conserved in BucL2 and is probably not involved in germline formation. Most teleosts seem to have lost Buc1, and the Buc2 paralog has probably acquired the role as germ cell determinant, while sub- or neofunctionalization of Buc1 and Buc2 might have occurred in species possessing both paralogs. Consistent with a function in germ plasm assembly, the salmon bucla paralog was shown to be maternally inherited, and the Bucla protein was localized to the embryonic cleavage furrows similar to that of injected zebrafish Buc-GFP, but also endogenous zebrafish Buc [36]. Further, salmon Bucla co-localized with Vasa in early oocytes in agreement with zebrafish Buc1 and Vasa [36]. The involvement of several salmon paralogs in the germline formation is supported by the co-localization of salmon Bucla and Buc2a in the putative Balbiani body during oogenesis and by the maternal mRNAs in the salmon embryo. Dosage balance has been described as an important process for the retention of duplicate genes after whole genome duplication events [62-64]. While overexpression of buc1 in the zebrafish embryo resulted in ectopic germ cells [23], appropriate mRNA levels are probably maintained by the three buc genes in the salmon embryo. Contrasting with the restricted expression of zebrafish buc1 in females, the extra-ovarian expression of the three salmon genes suggests additional functions not associated with germline formation.

\section{Conclusions}

Whereas zygotic induction has been thought to be the ancestral mechanism of germ cell specification, the long evolutionary history of Buc and the presence of maternal germ plasm in several basal vertebrates suggest that Buc played an ancestral role in germline formation. We propose that Buc functions as the common regulator of germ plasm assembly in vertebrates and has either been lost or has acquired a somatic function in lineages without germ plasm. In teleosts, duplicated Buc proteins are probably involved in both germline formation and somatic functions. Possible subfunctionalization or redundancy of the salmon Buc proteins in germ cell specification warrants further studies by targeted gene knockout.

\section{Methods}

\section{Identification of buc genes and conserved synteny}

Buc sequences were retrieved by searching the databases http://www.ncbi.nlm.nih.gov, http://www.ensembl.org (release 84), http://www.ambystoma.org/research/salamander-genome-project (axolotl, Ambystoma mexicanum), http://www.uniprot.org/taxonomy/7739 (amphioxus, Branchiostoma floridae), http://mosas.sysu.edu.cn/genome/ gbrowser_wel.php (Branchiostoma belcheri, http://www. uniprot.org/taxonomy/10224 (acorn worm, Saccoglossus 
kowalevskii). Accession numbers are given in Additional file 3: Table S1. Unannotated genes were identified by BLAST using known orthologs as query sequences and by examination of conserved flanking genes. Downloaded sequences were controlled by examination of sequence homology and presence of a conserved BUVE motif. Syntenic blocks were identified by searching for conserved neighbor genes in the given databases.

\section{Phylogenetic analyses}

A phylogenetic tree of vertebrate Buc was constructed using the Maximum Likelihood (ML) method. A total of 50 Buc peptide sequences from different species were imported to Mega6 [65]. Multiple sequence alignments were made using MUSCLE, and positions containing gaps and missing data were eliminated (Additional file 6: Figure S6). The best model for the alignment was chosen using the ML option ("Find the best DNA/protein models") provided by the software. The model with the lowest BIC (Bayesian Information Criterion) scores was chosen as it best describes the substitution pattern. Based on the BIC values the JTT (Jones-Taylor-Thornton) model was chosen [66]. To evaluate the tree topological stability, 100 bootstrap resamplings were made and all branches with less than 30 bootstrap confidence values were collapsed. The unrooted tree with the highest log likelihood was presented.

\section{Fish and tissue collection}

All fish material, including unfertilized eggs and sperm, were provided by AquaGen salmon breeding company (Trondheim, Norway). Fertilization was performed at the Aquaculture research station (Tromsø, Norway) according to the general protocol for salmon, and the fertilized eggs were incubated at a temperature of $5-6{ }^{\circ} \mathrm{C}$. The following stages were sampled for analyses: 1 ) unfertilized eggs and 2) 1000-cell stage 3) onset of gastrula 4) late gastrula and 5) segmentation stage. The embryonic stages were calculated by multiplying the incubation temperature (in ${ }^{\circ} \mathrm{C}$ ) with the number of days since fertilization. Three biological replicates of eggs and embryos were submerged in RNAlater (Ambion, Austin, Texas, USA) to be used for gene expression analyses.

Six females from each developmental stages of freshwater parr $(25 \mathrm{~g})$, seawater smolt $(80 \mathrm{~g})$ and adults of 2- and 3- years were anaesthetized in metacain (MS-222, Sigma-Aldrich, Oslo, Norway) and sacrificed before ovaries were removed. Additional organs (pituitary, heart, brain, muscle, head kidney, skin, gills and spleen) were collected from two 2-year old females for examination of extra-ovarian gene expression. All tissues were carefully excised and stored in RNAlater (Ambion, Austin, Texas, USA) according to the manufacturer's protocol. For immunohistochemistry, ovaries from three biological replicates of $80 \mathrm{~g}$ juvenile and 2-year old females were fixed in $4 \%$ paraformaldehyde (PFA), dehydrated in series of ethanol and finally stored in $70 \%$ ethanol at $-20{ }^{\circ} \mathrm{C}$.

\section{RNA extraction, CDNA synthesis and quantitative real-time RT-qPCR}

Total RNA was extracted from salmon tissues, eggs and embryos using TRIzol (Life Sciences) and PureLinkTM RNA mini kit (Ambion). On-column DNase treatment was performed using PureLinkTM DNase (Life Sciences) to remove traces of DNA and impurities. RNA concentration and purity was measured by NanoDrop ND-1000 spectrophotometer (Thermo Fisher Scientific, Wilmington, USA).

cDNAs were made using the AffinityScript cDNA synthesis kit (Agilent Technologies) in a $20 \mu \mathrm{l}$ reaction system according to the manufacturer's instructions. For tissue samples, 200 ng total RNA was reversetranscribed into cDNA, whereas 50 ng was used for eggs and embryos. Gene expression levels were quantified by real-time qPCR. The PCR primers (Additional file 7: Table S2) were designed using the Primer3 software and synthesized by Life Technologies. Eukaryotic elongation factor 1-alpha (eEf1-a) was used as a reference gene for calculating embryonic and ovarian mRNA levels. Melting curve analysis revealed that each primer pair produced only one product. Efficiency was checked from tenfold serial dilutions of cDNA for each primer pair. A $2 \times$ SYBR $^{\circ}$ Green PCR Mastermix (Roche Diagnostics, Mannheim, Germany), $0.8 \mathrm{mM}$ of each primer, and $4 \mu \mathrm{l}$ of 1:10 diluted cDNA template were mixed in $12 \mu \mathrm{l}$ reaction volumes. PCR was performed in duplicates in 96-well optical plates on Light Cycler 480 (Roche Diagnostics, Mannheim, Germany) under the following conditions: $95^{\circ} \mathrm{C}$ for $5 \mathrm{~min}$ (preincubation), $95{ }^{\circ} \mathrm{C}$ for $5 \mathrm{~s}, 60{ }^{\circ} \mathrm{C}$ for $15 \mathrm{~s}, 72{ }^{\circ} \mathrm{C}$ for $15 \mathrm{~s}$ (amplification), followed by $95^{\circ} \mathrm{C}$ for $5 \mathrm{~s}$ and $65^{\circ} \mathrm{C}$ for $1 \mathrm{~min}$ (melting curve); 45 amplification cycles were performed. Relative expression of mRNA was calculated using the $\Delta \Delta \mathrm{Ct}$ method [67]. Differences between control and tissues at different developmental stages were assessed with Student's $t$-test $(p<0.05)$.

\section{Immunohistochemistry (IHC)}

Specific antibodies against the three salmon Buc proteins were produced in rabbits by injection of KLH (keyhole limpet hemocyanin)-conjugated synthetic peptides derived from protein-specific epitopes following standard protocol (GenScript, Hong Kong). Similarly, antibodies against salmon Dazl and Dnd were produced against N-terminal epitopes in rabbits by GL Biochem Ltd (Shanghai, China). IHC was carried out on LR-white plastic (London Resin Company, EMS, England) $2 \mu \mathrm{m}$ thick ovarian sections. Permeabilization step was performed with $0.1 \%$ Triton X- 
100 in phosphate buffered saline-PBS (Sigma-Aldrich, Oslo, Norway) for $20 \mathrm{~min}$. Unspecific binding sites were blocked using $5 \%$ skimmed milk diluted in PBST (PBS with $0.1 \%$ Tween-20) for $3 \mathrm{~h}$. The sections were incubated over night at $4{ }^{\circ} \mathrm{C}$ with the Bucla, Buc2b, Vasa, Dnd and Dazl primary antibodies diluted in PBST and $2 \%$ skimmed milk. Negative controls were incubated with secondary antibodies only, whereas positive control was incubated with salmon specific collagen type 1 (Biologo, Germany) (Additional file 8: Figure S5). After washing in PBST, the sections were incubated with DyLight 549 (Jackson Immuno Research) secondary antibody diluted 1:400 for $2 \mathrm{~h}$. Final PBST wash was carried out before mounting in Dako fluorescent mounting medium (Glostrup, Denmark). All images were taken using a Zeiss Axio Observer Z1 microscope.

4-cell stage embryos used for IHC with Buc2b antibody were dechorionated and incubated in pre-chilled acetone for $20 \mathrm{~min}$ at $-20{ }^{\circ} \mathrm{C}$. This was followed by PBST wash and blocking in $5 \%$ sheep serum for $2 \mathrm{~h}$ at room temperature. After blocking, embryos were incubated with the primary antibody as described above. Next, embryos were thoroughly washed in PBST before the secondary antibody Alexa Fluor 488 (Life Technologies) was applied. This was followed with PBST washes and imaging using Lumar.

\section{Microinjections of zebrafish buc mRNA}

A zebrafish buc-GFP mRNA construct was kindly provided by Dr. Roland Dosch, University of Geneva, Switzerland) [35]. Salmon embryos at the 1-cell stage were injected with $\approx 200 \mathrm{ng} b u c$ mRNA in $0.05 \%$ phenol red solution and incubated at $5-6{ }^{\circ} \mathrm{C}$. A minimum of 100 embryos was injected at the 1 -cell stage, and at least $60 \%$ of them expressed Buc-GFP construct in the cleavage furrows. At segmentation, the number of embryos expressing Buc-GFP decreased to about $40 \%$. Images were taken at the 4-cell and segmentation stages using Lumar.

\section{Transmission electron microscopy (TEM)}

Fragments of ovarian tissues were fixed in $25 \%$ glutaraldehyde solution for $5 \mathrm{~h}$ at room temperature, and postfixed in a $1 \%$ osmium tetroxide in $0.1 \mathrm{M}$ cacodylate buffer for $1.5 \mathrm{~h}$ at room temperature. Samples were then dehydrated in a graded acetone series, and infiltrated and embedded in LR White (London Resin Company, EMS, England). Ultrathin sections $(70 \mathrm{~nm})$ were obtained with a Leica EM UC6 Ultramicrotome. The sections were stained with $4 \%$ uranyl acetate and $1 \%$ potassium permanganate for $5 \mathrm{~min}$, examined and photographed with a FEI Morgagni 268 transmission electron microscope operated at $80 \mathrm{kV}$.

\section{Additional files}

Additional file 1: Figure S1. Chromosome localization (A) and sequence alignment (B) of buc and buc-like (bucl) genes in cow and dog. Putative pseudogenes $(\Psi)$ contain premature stop codons $(*)$, which are ignored in the protein prediction. (DOCX $70 \mathrm{~kb}$ )

Additional file 2: Figure S2. Partial buc genes from eight primates including with predicted human $\mathrm{N}$-terminus (above) compared with ferret buc and predicted protein (below). The inserted A in primates results in a premature stop, while the deletion of the inserted base would introduce another stop as shown in italics on top. Translation start codon is mutated in gorilla. Chromosomal positions of the primate buc genes: Human; Chr5:129170048, Chimpaneze; Chr5:129813080, Gorilla;

Chr5:112518743, Orangutan; Chr5:130553556, Baboon; Chr6:122901841, Gibbon; Chr1:28463206, Macaque; Chr6:125569040, Vervet; Chr23:32116145. (DOCX $14 \mathrm{~kb})$

Additional file 3: Table S1. Accession numbers of vertebrate Buc and BucL proteins. (DOCX $17 \mathrm{~kb}$ )

Additional file 4: Figure S3. Partial Mexican axolotl Buc predicted from two contigs identified in the genome by Blasting against Xenopus Velo1. Sequence alignment revealed a single base deletion introducing a premature translation stop. The partial axolotl Buc shares $52 \%$ identity with Xenopus Velo1. (DOCX $15 \mathrm{~kb}$ )

Additional file 5: Figure S4. Conservation of the $\mathrm{N}$-terminal end in $\mathrm{A}$. Buc of various vertebrates, and B. BucL (-like) of zebrafish, salmon and spotted gar. Well conserved positions are shown in bold. (DOCX $15 \mathrm{~kb}$ )

Additional file 6: Figure S6. Multiple Buc sequence alignments from different species were obtained using MUSLE (multiple sequence comparison by log-expectation) (www.ebi.ac.uk/Tools/msa/muscle/). The alignments were imported to GenDoc for visual inspections. (PNG $891 \mathrm{~kb}$ )

Additional file 7: Table S2. Primer list for real-time GPCR (F-forward, R-reverse). (DOCX $16 \mathrm{~kb}$ )

Additional file 8: Figure S5. A. Negative control (secondary antibody alone) of immunostained salmon embryo at 4-cell stage shown in Fig. 4. B. Negative control (secondary antibody alone) and C. Positive control (collagen staining) of immunohistochemical staining of ovarian sections from maturing 2-year old salmon shown in Fig. 6. (DOCX $1930 \mathrm{~kb}$ )

\section{Acknowledgements}

We thank Roland Dosch for providing zebrafish Buc-GFP. Two anonymous reviewers are thanked for critically reading the manuscript and suggesting improvements.

Funding

This work was funded by the Norwegian Seafood Research Fund (FHF).

Availability of data and materials

The datasets supporting the results and conclusions of this article are included within the article and supplementary materials.

Authors' contributions

$H T$ conceived and designed the study together with AS and ØA. AS carried out the gene expression, IHC and TEM analyses. HJ was responsible for the phylogenetic analyses. ØA wrote the manuscript together with AS, and all authors approved the final version of the manuscript.

\section{Competing interests}

The authors declare that they have no competing interests.

\section{Consent for publication}

Not applicable.

\section{Ethics approval}

Fertilized eggs and alevins prior to exogenous feeding are exempted from the Norwegian Regulation on Animal Experimentation, and thus approval of the experimental protocol of this experiment by the Norwegian Animal Research Authority (NARA) was not needed. However, welfare and use of 
experimental animals were none the less performed in strict accordance with the Norwegian Animal Welfare Act and Regulation of Animal Experimentation.

\section{Author details}

${ }^{1}$ Norwegian University of Life Sciences (NMBU), PO Box 5003, N-1430 Ås, Norway. ${ }^{2}$ Nofima, PO Box 6122, N-9291, Tromsø, Norway. ${ }^{3}$ Nofima, PO Box 5010, N-1430 Ås, Norway.

\section{Received: 28 April 2016 Accepted: 14 October 2016}

\section{Published online: 26 October 2016}

\section{References}

1. Chatfield J, O'Reilly MA, Bachvarova RF, Ferjentsik Z, Redwood C, Walmsley M, Patient R, Loose M, Johnson AD. Stochastic specification of primordial germ cells from mesoderm precursors in axolotl embryos. Development. 2014;141:2429-40.

2. Günesdogan U, Magnusdottir E, Surani MA. Primordial germ cell specification: a context-dependent cellular differentiation event. Phil Trans R Soc Lond B Biol Sci. 2014;369:20130543.

3. Saitou M, Yamaji M. Primordial germ cells in mice. Cold Spring Harb Perspect Biol. 2012:4:a008375.

4. Seervai RN, Wessel GM. Lessons for inductive germline determination. Mol Reprod Dev. 2013;80:590-609.

5. Bachvarova RF, Crother BI, Johnson AD. Evolution of germ cell development in tetrapods: comparison of urodeles and amniotes. Evol Dev. 2009;11:603-9.

6. Extavour CG, Akam M. Mechanisms of germ cell specification across the metazoans: epigenesis and preformation. Development. 2003;130:5869-84.

7. Johnson AD, Drum M, Bachvarova RF, Masi T, White ME, Crother BI. Evolution of predetermined germ cells in vertebrate embryos: implications for macroevolution. Evol Dev. 2003;5:414-31.

8. Kloc M, Bilinski S, Chan AP, Allen LH, Zearfoss NR, Etkin LD. RNA localization and germ cell determination in Xenopus. Int Rev Cytol. 2001;203:63-91.

9. Hashimoto Y, Maegawa S, Nagai T, Yamaha E, Suzuki H, Yasuda K, Inoue K. Localized maternal factors are required for zebrafish germ cell formation. Dev Biol. 2004;268:152-61.

10. Haston KM, Tung JY, Reijo Pera RA. Dazl functions in maintenance of pluripotency and genetic and epigenetic programs of differentiation in mouse primordial germ cells in vivo and in vitro. PLoS One. 2009;4:0005654.

11. Koprunner M, Thisse C, Thisse B, Raz E. A zebrafish nanos-related gene is essential for the development of primordial germ cells. Genes Dev. 2001;15:2877-85.

12. Raz E. Primordial germ-cell development: the zebrafish perspective. Nat Rev Genet. 2003:4:690-700.

13. Tanaka SS, Toyooka Y, Akasu R, Katoh-Fukui Y, Nakahara Y, Suzuki R, Yokoyama M, Noce T. The mouse homolog of Drosophila Vasa is required for the development of male germ cells. Genes Dev. 2000;14:841-53.

14. Weidinger G, Stebler J, Slanchev K, Dumstrei K, Wise C, Lovell-Badge R, Thisse C, Thisse B, Raz E. dead end, a novel vertebrate germ plasm component, is required for zebrafish primordial germ cell migration and survival. Curr Biol. 2003;13:1429-34.

15. Youngren KK, Coveney D, Peng X, Bhattacharya C, Schmidt LS, Nickerson ML, Lamb BT, Deng JM, Behringer RR, Capel B, et al. The Ter mutation in the dead end gene causes germ cell loss and testicular germ cell tumours. Nature. 2005:435:360-4.

16. Houston DW, Zhang J, Maines JZ, Wasserman SA, King ML. A Xenopus DAZ-like gene encodes an RNA component of germ plasm and is a functional homologue of Drosophila boule. Development. 1998;125:171-80.

17. Johnson AD, Bachvarova RF, Drum M, Masi T. Expression of axolotl DAZL RNA, a marker of germ plasm: widespread maternal RNA and onset of expression in germ cells approaching the gonad. Dev Biol. 2001;234:402-15.

18. Knaut H, Pelegri F, Bohmann K, Schwarz H, Nusslein-Volhard C. Zebrafish vasa RNA but not its protein is a component of the germ plasm and segregates asymmetrically before germline specification. J Cell Biol. 2000;149:875-88.

19. Nagasawa K, Fernandes JM, Yoshizaki G, Miwa M, Babiak I. Identification and migration of primordial germ cells in Atlantic salmon, Salmo salar: characterization of vasa, dead end, and lymphocyte antigen 75 genes. Mol Reprod Dev. 2013;80:118-31.
20. Rengaraj D, Zheng YH, Kang KS, Park KJ, Lee BR, Lee SI, Choi JW, Han JY. Conserved expression pattern of chicken DAZL in primordial germ cells and germ-line cells. Theriogenology. 2010;74:765-76.

21. Tamori Y, Iwai T, Mita K, Wakahara M. Spatio-temporal expression of a DAZ-like gene in the Japanese newt Cynops pyrrhogaster that has no germ plasm. Dev Genes Evol. 2004;214:615-27.

22. Kloc M, Jedrzejowska I, Tworzydlo W, Bilinski SM. Balbiani body, nuage and sponge bodies- The germ plasm pathway players. Arthropod Struct Dev. 2014;43:341-8.

23. Bontems F, Stein A, Marlow F, Lyautey J, Gupta T, Mullins MC, Dosch R. Bucky ball organizes germ plasm assembly in zebrafish. Curr Biol. 2009;19:414-22.

24. Claussen M, Pieler T. Xvelo1 uses a novel 75-nucleotide signal sequence that drives vegetal localization along the late pathway in Xenopus oocytes. Dev Biol. 2004;266:270-84.

25. Dosch R, Wagner DS, Mintzer KA, Runke G, Wiemelt AP, Mullins MC. Maternal control of vertebrate development before the midblastula transition. Mutants from the zebrafish I. Dev Cell. 2004;6:771-80.

26. Marlow FL, Mullins MC. Bucky ball functions in Balbiani body assembly and animal-vegetal polarity in the oocyte and follicle cell layer in zebrafish. Dev Biol. 2008;321:40-50.

27. Nijjar S, Woodland HR. Protein interactions in Xenopus germ plasm RNP particles. PLoS One. 2013;8:e80077.

28. Ephrussi A, Dickinson LK, Lehmann R. Oskar organizes the germ plasm and directs localization of the posterior determinant nanos. Cell. 1991;66:37-50.

29. Ephrussi A, Lehmann R. Induction of germ cell formation by oskar. Nature. 1992;358:387-92.

30. Extavour CG. Long-lost relative claims orphan gene: oskar in a wasp. PLoS Genet. 2011;7:28.

31. Ewen-Campen B, Srouji JR, Schwager EE, Extavour CG. oskar predates the evolution of germ plasm in insects. Curr Biol. 2012;22:2278-83.

32. Heim AE, Hartung O, Rothhamel S, Ferreira E, Jenny A, Marlow FL. Oocyte polarity requires a Bucky ball-dependent feedback amplification loop. Development. 2014;141:842-54.

33. Grus WE, Shi P, Zhang YP, Zhang J. Dramatic variation of the vomeronasal pheromone receptor gene repertoire among five orders of placental and marsupial mammals. Proc Natl Acad Sci U S A. 2005;102:5767-72.

34. Skugor A, Slanchev K, Torgersen JS, Tveiten H, Andersen O. Conserved mechanisms for germ cell-specific localization of nanos3 transcripts in teleost species with aquaculture significance. Marine biotechnology (New York, NY). 2014;16:256-64.

35. Bromage NR, Cumaranatunga PRT. Egg production in rainbow trout. In: Muir JF, Roberts RJ, editors. Recent Advances in Aquaculture. London: Croom Helm; 1988. p. 65-138.

36. Riemer S, Bontems F, Krishnakumar P, Gomann J, Dosch R. A functional Bucky ball-GFP transgene visualizes germ plasm in living zebrafish. Gene Expr Patterns. 2015;18:44-52.

37. Yue H, Li C, Du H, Zhang S, Wei Q. Sequencing and de novo assembly of the gonadal transcriptome of the endangered Chinese sturgeon (Acipenser sinensis). PLoS One. 2015;10:e0127332.

38. Peng Z, Ludwig A, Peng Z, Ludwig A, Wang D, Diogo R, Wei Q, He S. Age and biogeography of major clades in sturgeons and paddlefishes (Pisces: Acipenseriformes). Mol Phylogenet Evol. 2007:42:854-62.

39. Zelazowska M, Kilarski W, Bilinski SM, Podder DD, Kloc M. Balbiani cytoplasm in oocytes of a primitive fish, the sturgeon Acipenser gueldenstaedtii, and its potential homology to the Balbiani body (mitochondrial cloud) of Xenopus laevis oocytes. Cell Tissue Res. 2007;329:137-45.

40. Saito T, Pšenička M, Goto R, Adachi S, Inoue K, Arai K, Yamaha E. The origin and migration of primordial germ cells in sturgeons. PLoS One. 2014;9:e86861

41. Ye H, Li CJ, Yue HM, Yang XG, Wei QW. Differential expression oif fertility genes boule and dazl in Chinese strugeon (Acipenser sinensis), a basal fish. Cell Tissue Res. 2015;360:413-25.

42. Prisco M, Ricchiari L, Andreuccetti P. An ultrastructural study of germ cells during ovarian differentiation in Torpedo marmorata. Anat Rec. 2001;263:239-47.

43. Biscotti MA, Gerdol M, Canapa A, Forconi M, Olmo E, Pallavicini A, Barucca M, Schartl M. The lungfish transcriptome: a glimpse into molecular evolution events at the transition from water to land. Sci Rep. 2016;6:21571.

44. Amemiya CT, Alföldi J, Lee AP, Fan S, Philippe H, Maccallum I, Braasch I, Manousaki T, Schneider I, Rohner N, Organ C, Chalopin D, Smith JJ, 
Robinson M, Dorrington RA, Gerdol M, Aken B, Biscotti MA, Barucca M, Baurain D, Berlin AM, Blatch GL, Buonocore F, Burmester T, Campbell MS, Canapa A, Cannon JP, Christoffels A, De Moro G, Edkins AL, Fan L, Fausto AM, Feiner N, Forconi M, Gamieldien J, Gnerre S, Gnirke A, Goldstone JV, Haerty W, Hahn ME, Hesse U, Hoffmann S, Johnson J, Karchner SI, Kuraku S, Lara M, Levin JZ, Litman GW, Mauceli E, Miyake T, Mueller MG, Nelson DR, Nitsche A, Olmo E, Ota T, Pallavicini A, Panji S, Picone B, Ponting CP, Prohaska SJ, Przybylski D, Saha NR, Ravi V, Ribeiro FJ, Sauka-Spengler T, Scapigliati G, Searle SM, Sharpe T, Simakov O, Stadler PF, Stegeman JJ, Sumiyama K, Tabbaa D, Tafer H, Turner-Maier J, van Heusden P, White S, Williams L, Yandell M, Brinkmann H, Volff JN, Tabin CJ, Shubin N, Schartl M, Jaffe DB, Postlethwait JH, Venkatesh B, Di Palma F, Lander ES, Meyer A, Lindblad-Toh K. The African coelacanth genome provides insights into tetrapod evolution. Nature. 2013;496:311-6.

45. Wu HR, Chen YT, Su YH, Luo YJ, Holland LZ, Yu JK. Asymmetric localization of germline markers Vasa and Nanos during early development in the amphioxus Branchiostoma floridae. Dev Biol. 2011;353:147-59.

46. Zhang QJ, Luo YJ, Wu HR, Chen YT, Yu JK. Expression of germline markers in three species of amphioxus supports a preformation mechanism of germ cell development in cephalochordates. EvoDevo. 2013;4:17.

47. Kumano G, Kawai N, Nishida H. Macho-1 regulates unequal cell divisions independently of its function as a muscle determinant. Dev Biol. 2010;344:284-92.

48. Kumano G, Takatori N, Negishi T, Takada T, Nishida H. A maternal factor unique to ascidians silences the germline via binding to P-TEFb and RNAP ॥ regulation. Curr Biol. 2011;21:1308-13.

49. Makabe KW, Nishida H. Cytoplasmic localization and reorganization in ascidian eggs: role of postplasmic/PEM RNAs in axis formation and fate determination. Wiley Interdiscip Rev Dev Biol. 2012;1:501-18.

50. Sardet C, Dru P, Prodon F. Maternal determinants and mRNAs in the cortex of ascidian oocytes, zygotes and embryos. Biol Cell. 2005;97:35-49.

51. Extavour CGM. Evolution of the bilaterian germ line: lineage origin and modulation of specification mechanisms. Integr Comp Biol. 2007;47:770-85.

52. Berekelia LA, Ponomarev MB, Mikriukov AA, Luchinskaia NN, Beliavskii AV. Molecular mechanisms of germ cell line determination in animals. Mol Biol. 2005;39:664-77.

53. Ewen-Campen B, Schwager EE, Extavour CG. The molecular machinery of germ line specification. Mol Reprod Dev. 2010;77:3-18.

54. Herpin A, Rohr S, Riedel D, Kluever N, Raz E, Schartl M. Specification of primordial germ cells in medaka (Oryzias latipes). BMC Dev Biol. 2007;7:3

55. Houston DW, King ML. Germ plasm and molecular determinants of germ cell fate. Curr Top Dev Biol. 2000;50:155-81.

56. Smith LD. The role of a "germinal plasm" in the formation of primordial germ cells in Rana pipiens. Dev Biol. 1966;14:330-47.

57. Johnson AD, Alberio R. Primordial germ cells: the first cell lineage or the last cells standing? Development. 2015;142:2730-9.

58. Johnson AD, Richardson E, Bachvarova RF, Crother BI. Evolution of the germ line-soma relationship in vertebrate embryos. Reproduction. 2011:141:291-300.

59. Cannatella D, Hillis D. Amphibian relationships: phylogenetic analysis of morphology and molecules. Herpetol Monogr. 1993;7:1-7.

60. Milner AR. The paleozoic relatives of lissamphibians. Herpetol Monogr. 1993;7:8-27.

61. Bachvarova RF, Crother BI, Manova K, Chatfield J, Shoemaker CM, Crews DP, Johnson AD. Expression of Dazl and Vasa in turtle embryos and ovaries: evidence for inductive specification of germ cells. Evol Dev. 2009;11:525-34.

62. Birchler JA, Veitia RA. Protein-protein and protein-DNA dosage balance and differential paralog transcription factor retention in polyploids. Front Plant Sci. 2011;2:64.

63. Hughes T, Ekman D, Ardawatia H, Elofsson A, Liberles DA. Evaluating dosage compensation as a cause of duplicate gene retention in Paramecium tetraurelia. Genome Biol. 2007;8:213.

64. Teufel Al, Liu L, Liberles DA. Models for gene duplication when dosage balance works as a transition state to subsequent neo-or subfunctionalization. BMC Evol Biol. 2016;16:45.

65. Tamura K, Stecher G, Peterson D, Filipski A, Kumar S. MEGA6: Molecular Evolutionary Genetics Analysis version 6.0. Mol Biol Evol. 2013;30:2725-9.

66. Jones DT, Taylor WR, Thornton JM. The rapid generation of mutation data matrices from protein sequences. Comput Appl Biosci. 1992;8:275-82.

67. Pfaffl MW. A new mathematical model for relative quantification in real-time RT-PCR. Nucleic Acids Res. 2001;29:e45.

\section{Submit your next manuscript to BioMed Central and we will help you at every step:}

- We accept pre-submission inquiries

- Our selector tool helps you to find the most relevant journal

- We provide round the clock customer support

- Convenient online submission

- Thorough peer review

- Inclusion in PubMed and all major indexing services

- Maximum visibility for your research

Submit your manuscript at www.biomedcentral.com/submit 